\title{
Similarity Patterns and Stability of Environmental Response in Sunflower Hybrids
}

\author{
V. Alba, ${ }^{1}$ G. B. Polignano, ${ }^{2}$ C. Montemurro, ${ }^{1}$ W. Sabetta, ${ }^{1}$ V. Bisignano, ${ }^{2}$ M. Turi, ${ }^{3}$ \\ S. Ravaglia, ${ }^{4}$ A. Troccoli, ${ }^{5}$ S. A. Colecchia, ${ }^{5}$ E. Alba, ${ }^{6}$ and A. Blanco ${ }^{1}$ \\ ${ }^{1}$ Section of Genetics and Breeding, Di.B.C.A., University of Bari, 70126 Bari, Italy \\ ${ }^{2}$ Institute of Plant Genetics, CNR, 70126 Bari, Italy \\ ${ }^{3}$ University Farm "A. Servadei”, University of Udine, 33100 Udine, Italy \\ ${ }^{4}$ Società Italiana Sementi (S.I.S.), Bologna, 40068 San Lazzaro di Savena, Italy \\ ${ }^{5}$ Cereal Research Centre, CRA, 71122 Foggia, Italy \\ ${ }^{6}$ Department of Biology Biotechnology and Agro-Forestry, University of Basilicata, 85100 Potenza, Italy
}

Correspondence should be addressed to G. B. Polignano, giambattista.polignano@igv.cnr.it

Received 20 July 2010; Revised 12 October 2010; Accepted 13 October 2010

Academic Editor: Rodomiro Ortiz

Copyright () 2010 V. Alba et al. This is an open access article distributed under the Creative Commons Attribution License, which permits unrestricted use, distribution, and reproduction in any medium, provided the original work is properly cited.

\begin{abstract}
The rationale for the following research was to analyse the response of sunflower hybrids to different sowing dates and to evaluate hybrid response to critical environmental conditions. The data used are from an experiment conducted in a location-year combination over a period of two years (2007-09) in southern Italy. Eleven hybrids were tested following a randomized complete block design with three replications at each location-year combination. Eight agronomic characters including seed oil content were recorded. Classification and ordination procedures were used to investigate hybrid performance in relation to three different sowing dates. Combined analysis of variance showed that hybrids, location-year combination, sowing date and their interactions were highly significant for all characters. Hybrid performances were classified by cluster analysis into groups that were differentiable in terms of means and stability. The first three components accounted for $74 \%, 82 \%$, and $87 \%$ of the total variation for the first, second and third sowing date respectively. Plotting component one against component two along Euclidean axes should therefore provide a reasonable representation of the spatial arrangements of hybrid performances in the original multi-dimensional space. The applied statistical method gives full information on hybrid performances similarity.
\end{abstract}

\section{Introduction}

Sunflower (Helianthus annuus L.) is one of the most cultivated and widespread oilseed crops. In recent years sunflower seed production has decreased, compared to the four major oilseeds (soybean, rapeseed, cottonseed, and groundnut). This is because sunflower continues to be allocated to marginal environments and soils with low fertility where drought and high temperatures may continually impair the yield per unit area (see review [1]). Conventionally, sunflower is sown around mid March; grain filling and oil accumulation are reached in June and July, when high evaporative demand and rare rainfall events take place. Although the sunflower crop may rely on stored soil moisture, it remains subject to water deficits and rainfall during the growing season, which then results in low yields, ranging from 500 to $2500 \mathrm{~kg} \mathrm{ha}^{-1}$ across location and time [2]. In Southern Italy environmental factors such as water deficit and summer drought, typical of the Mediterranean climate, may represent a limit for all spring-planted crops as well as for sunflower. Rainfall, which ranges from 200 to $600 \mathrm{~mm}_{\text {year }}{ }^{-1}$ and is generally concentrated in autumnspring, does not satisfy the demands of the crop. To take as an example, a sunflower crop, sown at a density of 5 plants $\mathrm{m}^{-2}$, produces plants that weigh on average $180 \mathrm{~g}$ dry matter and yet consume $3825 \mathrm{~m}^{3} \mathrm{ha}^{-1}$ of water [3]. Since, in many Mediterranean areas, water is not easily affordable or readily available, avoidance of high-evaporative-demand periods has been advocated as a strategy to increase crop productivity under conditions of drought [4]. 
Sunflower satisfies water demand by exploiting water soil reserves through the architecture of its root apparatus, and responding to available soil water located below normal rooting depths better than small grain crops such as wheat [5]. This enables sunflower to overcome short periods of water deficit. An agronomic technique may also be used to bypass water scarcity by moving sowing to autumn-winter and so take advantage of the rainy seasons during the delicate phases of vegetative growth and avoid drought stress during grain-filling. Critical climatic conditions during flowering and all periods of vegetative growth can have negative effects on crop yield. Characteristics that are associated with good vegetative growth such as days from sowing to maturity, plant height, head diameter, seed weight, and disease resistance $[6,7]$ are generally associated with high yield. During flowering sunflower is most susceptible to water deficits, which results in considerable yield decrease, since fewer flowers reach full development, leading to drastic reduction in both yield, and oil content [8]. While sunflower is a typical summer crop [9], it can also sustain small amounts of water and withstand temperatures up to $-5^{\circ} \mathrm{C}$ during germination and emergency phases, while storing its germinating efficiency over a wide temperature range $[3,10]$. Crop growth, on the other hand, may be severely limited by low temperatures. Damage to apical buds due to extreme environmental conditions may lead to branching, negatively associated with crop yield (see review [1]), and increase the duration of the entire crop cycle, which for sunflower cultivars ranges from 75 to 150 days [11].

Sowing date experiments for productive performance or susceptibility/resistance to certain pathogens have been tried with many crops such as Glycine max L. (Merr.) [12, 13], Mentha arvensis L. [14], Lilium auratum L. [15], Crambe abyssinicia Hochst and Brassica spp. [16], Cicer spp. [17], Oryza sativa L. [18]. With sunflower, sowingdate studies have focused mainly on comparing summer to spring and autumn sowing [19-23]. Gimeno et al. [4] have tested the potential of three hybrids under winter conditions in a Mediterranean climate by performing seven sowing dates at 15-30 days intervals starting from the 15th December. Seed yield, averaged over a four-year experiment, increases by $55 \%$ when sowing date is shifted from midMarch to mid December. The hypothesis was that winter sowing of sunflower, which was, in any case, irrigated, would have increased the probability of avoiding summer drought and consequently of producing higher dry-land yields. Research on sunflower behaviour exploiting winter rainfall in Mediterranean areas is not at present available. An advantage of sunflower autumn-winter sowing cycle can be seen in farming practices in Southern Italy where a crop system based on the durum wheat monoculture is used to prevent pest infestation arising from cropping the same soil $[24,25]$. Johnston et al. [26] have reported an increase in wheat grain yield when the cereal is preceded by an oilseed crop in rotation, thus confirming the negative effect of monoculture on wheat production. More, Halvorson et al. [5] have confirmed that sunflower helps reduce potential for saline-seep development, and improves crop-rotation diversity and root-zone water uptake efficiency.
The present study has been carried out to analyse the response of sunflower hybrids to different autumn-winter sowing dates and to evaluate hybrid response to critical conditions of low winter temperature and water shortage. Application of pattern analysis to examine responses of sunflower hybrids to changing environmental conditions are beyond the scope of this study.

\section{Material and Methods}

2.1. Study Areas. Research, which was conducted at the Valenzano experimental fields of the Agricultural Faculty of Bari, Italy in 2007-2008 and 2008-2009 and at the Cereal Research Centre, Foggia, Italy in 2007-2008, was based on three location-year combinations: Valenzano 2007 (code 1), Valenzano 2008 (2), and Foggia 2007 (3). Temperatures and rainfall at Valenzano were recorded by the Mediterranean Agronomic Institute of Bari; Foggia was equipped with a weather station. The distribution of monthly average rainfall and the trend of monthly average minimum and maximum temperatures for the two experimental stations are shown in Figure 1. Valenzano is situated at $41^{\circ} 01^{\prime} 17^{\prime \prime} \mathrm{N} 16^{\circ} 54^{\prime} 22^{\prime \prime} \mathrm{E}$ at $118 \mathrm{~m} \mathrm{ASL}$. The climate is typically Mediterranean with an average temperature of $15.0^{\circ} \mathrm{C}$ and an average minimum temperature of $9.8^{\circ} \mathrm{C}$ during the period from November to July for both years of the experiment. Peaks of $-2.5^{\circ} \mathrm{C}$ and $-1.5^{\circ} \mathrm{C}$ occurred during December 2007 and February 2009, respectively. During the trial held at Valenzano $2007 / 08$, total rainfall was $499.6 \mathrm{~mm}$, with the highest concentrations, $146.6 \mathrm{~mm}$, in December and the lowest, $13.6 \mathrm{~mm}$ in February. In the 2008/09 trial, total rainfall was $882.4 \mathrm{~mm}$, with the highest concentrations, $175.8 \mathrm{~mm}$ in January and the lowest, $4.4 \mathrm{~mm}$, in May. Foggia is situated at $41^{\circ} 25^{\prime} 31^{\prime \prime} \mathrm{N} 15^{\circ} 33^{\prime} 17^{\prime \prime} \mathrm{E}$ at $71 \mathrm{~m} \mathrm{ASL}$. The climate is subhumid Mediterranean with an average temperature of $13^{\circ} \mathrm{C}$ during the period from November to July, and an average minimum temperature of $7.7^{\circ} \mathrm{C}$. Peaks of $-5.0^{\circ} \mathrm{C}$ were recorded in December 2007. The highest average temperature was $19.0^{\circ} \mathrm{C}$. Total rainfall was $337 \mathrm{~mm}$, with the highest concentrations, $86 \mathrm{~mm}$, in March and the lowest, $4.5 \mathrm{~mm}$ in July.

2.2. Experimental Trials. Eleven commercial and experimental sunflower hybrids (Table 1), genetically constituted for a conventional growth cycle, were tested at three early autumn-winter sowing dates (S1, S2, and S3, resp.) following a randomized complete block design with three replications at Valenzano and Foggia in 2007/2008. At 2-4 true leaf stage, all experiments were adjusted to a density of 5 plants $\mathrm{m}^{-2}$, spaced $70 \mathrm{~cm}$ between rows and $30 \mathrm{~cm}$ on row, in plots of $8.4 \mathrm{~m}^{2}$. Sowing was set up for both Valenzano and Foggia at 20-day intervals from the first half of November. Any differences between environments and dates occurred mainly because of adverse weather conditions (Table 2). Standard agronomic practices were performed in the two environments with Phosphate-Diammonium 18:46 $\left(250 \mathrm{~kg} \mathrm{ha}^{-1}\right)$ in presowing and Nitrogen-Ammonium 34 $\left(250 \mathrm{~kg} \mathrm{ha}^{-1}\right)$ during floral initiation. Pendimettalin $31.7 \mathrm{~g}$ 
TABLE 1: List of commercial and experimental sunflower hybrids tested in anticipated sowing dates in 2007-08 and 2008-09 at Valenzano and Foggia (Southern Italy), specified for productive attitude and source.

\begin{tabular}{lccc}
\hline Code & Hybrid & Attitude & Source \\
\hline A & Solaris & Conventional & PANNAR(SIS) \\
B & Montijo & High oleic & DANISCO \\
C & Proleic 204 & High oleic & SIS \\
D & Carnia & High oleic & SIS \\
E & Alliance RM & Conventional & SIS \\
F & Kasol & Conventional & SIS \\
G & Best & High oleic & DANISCO \\
H & 1-UD & Conventional & University of Udine \\
I & 2-UD & High oleic & University of Udine \\
J & 3-UD & Conventional & University of Udine \\
K & 4-UD & High oleic & University of Udine \\
\hline
\end{tabular}

$\left(4 \mathrm{l} \mathrm{ha}{ }^{-1}\right)$ was employed for weed control in presowing, while insect control was performed with Carbaril. Germination $\%$, days to germination ( $70 \%$ of plant germinated), days to flowering ( $70 \%$ of plant flowered), stem branching, plant height, head diameter, 1000 seed weight, seed yield, and oil content were all recorded. Seed oil content (\% on d.m.) was evaluated in three replicates per hybrid by means of nuclear magnetic resonance [27].

2.3. Statistical Analyses. Pooled analysis of variants across location-year combinations and sowing date was used to obtain estimates of variants. Hybrids and replicate effects were considered as fixed effects, and location-year combination and sowing date were assumed to be random. Means separation was performed by a Duncan test and plot means were then processed using multivariate analysis $[28,29]$. A pattern analysis approach based on ordination and classification was used to identify differences among hybrids in mean performances and responses across seasons. Data analysis involved two steps: (1) analysis of main components to summarise information contained in original traits in a smaller and unrelated number of variables to be represented on a smaller number of orthogonal axes; (2) cluster analysis utilising principal components to differentiate hybrid behaviour during growing seasons. Following this approach, a stable line was drawn to show similar behaviour in different years, with each hybrid represented by three vectors that correspond to hybrid behaviour for each year. Hybrids were then clustered starting with the two most similar behaviours and continuing until a single cluster was arrived at. GLM, PRIN COMP, and PROC CLUSTER procedures from the SAS (1989) [30] statistical software package were used to perform statistical analysis. Ward's minimum variance method was carried out to define cluster groups and to establish similarity and dissimilarity among hybrid performances. The number of significant clusters was determined by selecting a possibly high $\mathrm{R}^{2}$ (RSQ), Pseudo F (PSF), and cubic clustering criterion (CCC) combined with a small value of Pseudo-T ${ }^{2}\left(\mathrm{PST}^{2}\right)$ and a larger $\mathrm{PST}^{2}$ for the

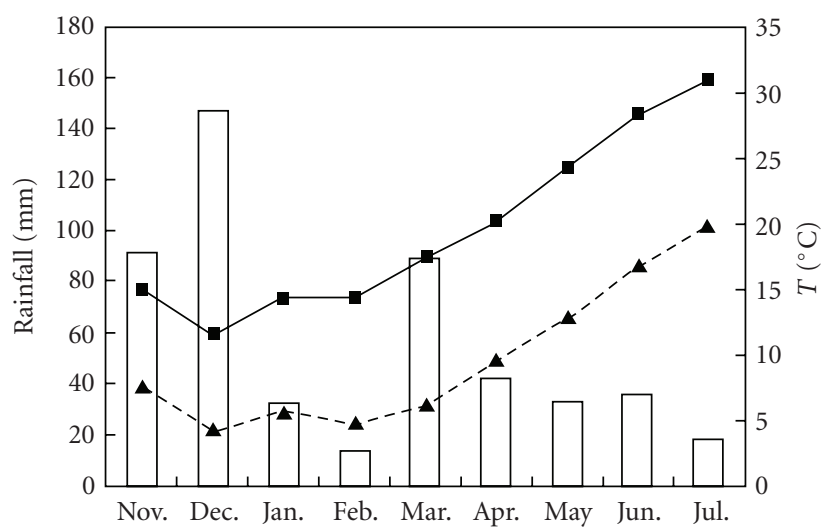

(a)

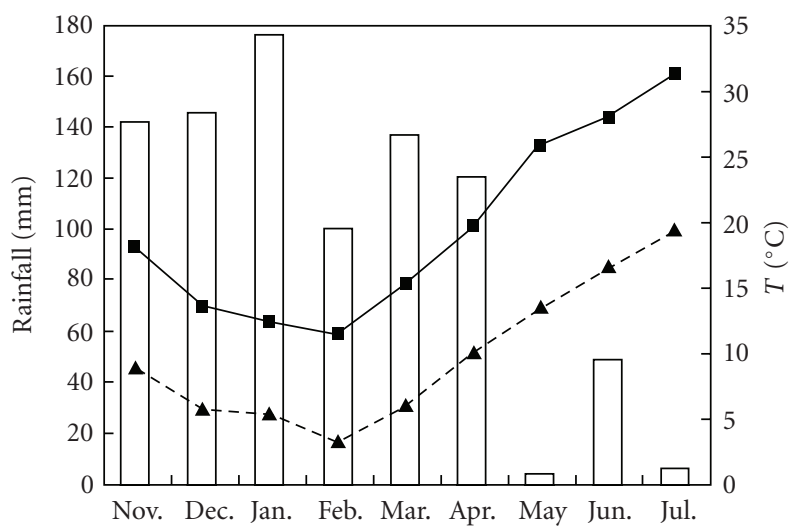

(b)

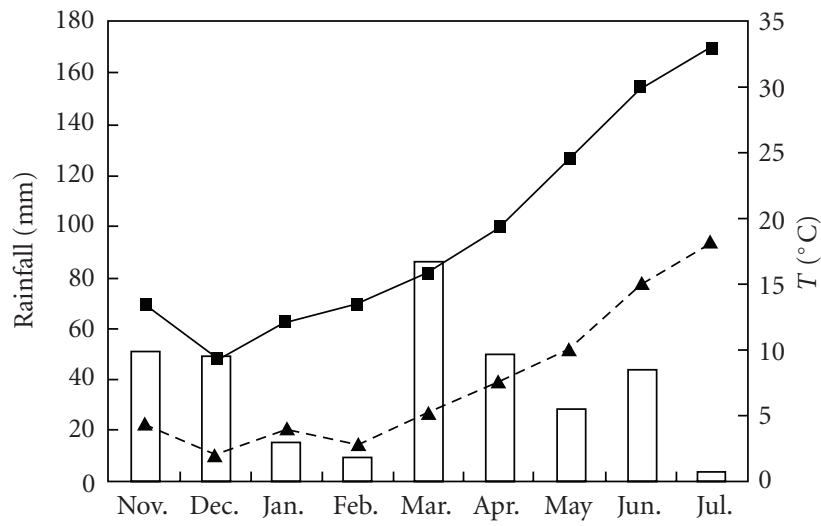

$\square$ Rainfall (mm)
$\rightarrow$ - Mean maximum temperature $\left({ }^{\circ} \mathrm{C}\right)$
$-\mathbf{A}$ - Mean minimum temperature $\left({ }^{\circ} \mathrm{C}\right)$

(c)

FIgURE 1: Trend of average minimum (dashed line) and average maximum monthly temperatures (solid line) and distribution of monthly rainfall (bars) in Valenzano 2007/08 (a), Valenzano 2008/09 (b), and Foggia 2007/08 (c).

resulting cluster fusion [31]. Clusters were finally interpreted according to hybrid frequency. Clustering results were then combined with results from principal component analysis as 
TABLE 2: Sowing dates (S1, S2, and S3 code), temperature sums, cycle duration and rainfall parameters for three different anticipated sowing dates in 2007/08 at three location-year combinations (1, 2, and 3 code).

\begin{tabular}{|c|c|c|c|c|c|c|}
\hline Location-year & Code & Sowing date & Code & $T$-sum* $\left({ }^{\circ} \mathrm{C}\right.$ days $)$ & Cycle duration (days) & Rainfall (mm) \\
\hline \multirow{3}{*}{ Valenzano $07 / 08$} & \multirow{3}{*}{1} & 08th Nov 2007 & S1 & 2831 & 250 & 464.4 \\
\hline & & 27th Nov 2007 & S2 & 2334 & 230 & 406.2 \\
\hline & & 2nd Jan 2008 & S3 & 2225 & 195 & 237.4 \\
\hline \multirow{3}{*}{ Valenzano 08/09 } & \multirow{3}{*}{2} & 21st Nov 2008 & S1 & 2448 & 250 & 790.0 \\
\hline & & 10th Dec 2008 & S2 & 2338 & 230 & 683.4 \\
\hline & & 31st Dec 2008 & S3 & 2241 & 210 & 593.8 \\
\hline \multirow{3}{*}{ Foggia $07 / 08$} & \multirow{3}{*}{3} & 16th Nov 2007 & S1 & 2214 & 258 & 312.0 \\
\hline & & 29th Nov 2007 & S2 & 2174 & 245 & 290.0 \\
\hline & & 20th Dec 2007 & S3 & 2121 & 224 & 248.3 \\
\hline
\end{tabular}

${ }^{*}$ Temperature sums were calculated using a base temperature of $5^{\circ} \mathrm{C}$.

TABLE 3: Analysis of variance for eight biometric traits observed in 11 sunflower hybrids over three sowing dates (S) and three location-year combinations (L).

\begin{tabular}{|c|c|c|c|c|c|c|c|c|c|}
\hline $\begin{array}{l}\text { Source of } \\
\text { variation }\end{array}$ & $\mathrm{df}$ & $\begin{array}{l}\text { Germination } \\
(\%)\end{array}$ & $\begin{array}{l}\text { Days to } \\
\text { flowering }\end{array}$ & $\begin{array}{l}\text { Plant height } \\
(\mathrm{cm})\end{array}$ & $\begin{array}{l}\text { Branching } \\
\text { (plants \%) }\end{array}$ & $\begin{array}{c}\text { Head } \\
\text { diameter } \\
(\mathrm{cm})\end{array}$ & $\begin{array}{l}1000 \text { seed } \\
\text { weight }(g)\end{array}$ & $\begin{array}{l}\text { Seed yield } \\
\left(\mathrm{tha}^{-1}\right)\end{array}$ & $\begin{array}{l}\text { Oil content } \\
\text { (\% d.m.) }\end{array}$ \\
\hline $\begin{array}{l}\text { Location/year } \\
\text { (L) }\end{array}$ & 2 & $1.27^{* * *}$ & $9100.01^{* * *}$ & $6497.79^{* * *}$ & $11.97^{* * *}$ & $1872.21^{* * *}$ & $1652.14^{* * *}$ & $22.30^{* * *}$ & $0.06^{* * *}$ \\
\hline Sowing date (S) & 2 & $0.15^{* * *}$ & $22927.08^{* * *}$ & $4788.61^{* * *}$ & $2.36^{* * *}$ & $22.50^{* * *}$ & $3214.65^{* * *}$ & $0.59^{* * *}$ & $0.03^{* * *}$ \\
\hline $\mathrm{L} \times \mathrm{S}$ & 4 & $0.07^{* * *}$ & $589.37^{* * *}$ & $2971.85^{* * *}$ & $0.71^{* * *}$ & 1.50 n.s. & $457.72^{* * *}$ & $0.62^{* * *}$ & $0.02^{* * *}$ \\
\hline $\operatorname{Rip}(L \times S)$ & 18 & 0.02 n.s. & 5.39 n.s. & $160.86^{* *}$ & $0.06^{* * *}$ & $7.14^{* * *}$ & 36.89 n.s. & 0.13 n.s. & 0.00 n.s. \\
\hline Hybrid (H) & 10 & $0.29 * * *$ & $458.75^{* * *}$ & $2922.34^{* * *}$ & $0.16^{* * *}$ & $42.32^{* * *}$ & $1089.09^{* * *}$ & $2.22 * * *$ & $0.02^{* * *}$ \\
\hline $\mathrm{H} \times \mathrm{L}$ & 20 & $0.03^{* * *}$ & $75.52^{* * *}$ & $388.74^{* * *}$ & $0.08^{* * *}$ & $11.40^{* * *}$ & $244.38^{* * *}$ & $0.73^{* * *}$ & $0.01^{* * *}$ \\
\hline $\mathrm{H} \times \mathrm{S}$ & 20 & $0.04^{* * *}$ & $62.81^{* * *}$ & $316.11^{* * *}$ & $0.08^{* * *}$ & $7.88^{* * *}$ & $123.19^{* * *}$ & $0.31^{* * *}$ & $0.00^{* * *}$ \\
\hline $\mathrm{H} \times \mathrm{L} \times \mathrm{S}$ & 40 & 0.01 n.s. & $43.69^{* * *}$ & 60.19 n.s. & $0.05^{* * *}$ & $7.43^{* * *}$ & $39.12^{* *}$ & $0.15^{* * *}$ & $0.00^{* * *}$ \\
\hline Pooled error & 180 & 0.01 & 5.48 & 65.08 & 0.02 & 3.17 & 25.67 & 0.08 & 0.00 \\
\hline Total & 296 & & & & & & & & \\
\hline Hybrids mean & & 86 & 161 & 108.2 & 36 & 14.9 & 57.9 & 1.41 & 40 \\
\hline C. V. & & 12.53 & 1.46 & 7.46 & 41.44 & 11.97 & 8.75 & 20.20 & 4.38 \\
\hline
\end{tabular}

$* * * P \leq 0.01$

${ }^{* *} P \leq 0.05$

a visual aid for discerning clusters in subsequent graphical representations obtained using Stat Graph procedure from STATISTICA for Windows (StatSoft, 1995) [32].

\section{Results}

Location and year, temperature sums, cycle duration and rainfall $(\mathrm{mm})$ for each sowing date are shown in Table 2. Since sunflower needs to accumulate a number of hours above $5^{\circ} \mathrm{C}$ to reach physiological maturity and to complete the entire cycle, an increase in cycle duration, expressed as days from sowing time was evident for all sowing dates in both environments. Differences in location-year combination were also noted for rainfall. Although some of the trial received apparently optimal rainfall for completion of the plant cycle under nonstressed conditions, rainfall distribution was not entirely uniform (Figure 1). Rainfall was mostly concentrated in the winter period that is, when the plant was in "vegetative rest" due to low temperatures and radiation.

Combined analysis of variance showed that both sowing date, location-year, and interactions between location year and sowing date were highly significant for all traits (Table 3 ). Means and variation coefficients (CV) for all hybrids at each sowing date $(\mathrm{S})$ and location-year combination are given in Table 4. Germination did not seem to be a limiting factor for sunflower sown in autumn-winter, thus confirming its ability to store seed germination power despite low temperatures. Days to flowering decreased from S1 to S3 in all locationyear combinations indicating the high influence of stressed environment. Plant height was on average higher than in autumn-winter sowing dates S1 and S2. The phenomenon of branched plants was statistically different for all locationyear combinations. While it was almost negligible in S2 and S3, suggesting that later sowing may represent a "cold escape strategy" to prevent floral bud injuries; this was not 
TABLE 4: Mean values of eleven sunflower hybrids for three anticipated sowing dates (S1, S2, and S3) in three location-year combinations for eight biometric traits.

\begin{tabular}{|c|c|c|c|c|c|c|c|c|c|}
\hline $\begin{array}{l}\text { Sowing } \\
\text { date }\end{array}$ & Location-year & $\begin{array}{c}\text { Germination } \\
(\%)\end{array}$ & $\begin{array}{l}\text { Days to } \\
\text { flowering }\end{array}$ & $\begin{array}{l}\text { Plant height } \\
(\mathrm{cm})\end{array}$ & $\begin{array}{l}\text { Branching } \\
\text { (plants\%) }\end{array}$ & $\begin{array}{c}\text { Head } \\
\text { diameter } \\
(\mathrm{cm})\end{array}$ & $\begin{array}{l}1000 \text { seed } \\
\text { weight }(\mathrm{g})\end{array}$ & $\begin{array}{l}\text { Seed yield } \\
\left(\mathrm{tha}^{-1}\right)\end{array}$ & $\begin{array}{l}\text { Oil content } \\
(\% \mathrm{~d} . \mathrm{m} .)\end{array}$ \\
\hline \multirow{4}{*}{ S1 } & Valenzano 2007 & $95 a$ & $183 a$ & $88.6 a$ & $58 a$ & $17.0 a$ & $59.6 a$ & $1.35 a$ & $42 a$ \\
\hline & Valenzano 2008 & $95 a$ & $172 b$ & $92.3 b$ & $25 b$ & $10.6 b$ & $66.4 b$ & $0.90 b$ & $35 b$ \\
\hline & Foggia 2007 & $79 b$ & $164 c$ & $116.0 c$ & $78 c$ & $18.7 c$ & $66.7 b$ & $1.72 c$ & $39 c$ \\
\hline & Mean & 90 & 173 & 100.3 & 53 & 15.4 & 64.2 & 1.32 & 38 \\
\hline \multirow{4}{*}{ S2 } & Valenzano 2007 & $93 a$ & $175 a$ & $111.5 a$ & $5 a$ & $16.5 a$ & $57.8 a$ & $1.72 a$ & $43 a$ \\
\hline & Valenzano 2008 & $88 a$ & $167 b$ & $100.9 b$ & $5 a$ & $9.5 b$ & $53.8 a$ & $0.83 b$ & $41 b$ \\
\hline & Foggia 2007 & $73 b$ & $153 c$ & $119.3 c$ & $76 b$ & $17.5 a$ & $60.2 b$ & $1.83 a$ & $38 c$ \\
\hline & Mean & 84 & 165 & 110.6 & 28 & 14.5 & 56.2 & 1.45 & 41 \\
\hline \multirow{4}{*}{ S3 } & Valenzano 2007 & $86 a$ & $147 a$ & $122.9 a$ & $2 a$ & $16.7 a$ & $51.7 a$ & $1.75 a$ & $44 a$ \\
\hline & Valenzano 2008 & $95 b$ & $150 b$ & $103.7 b$ & $2 a$ & $9.7 b$ & $47.1 b$ & $0.88 b$ & $44 a$ \\
\hline & Foggia 2007 & $65 c$ & $133 c$ & $114.7 c$ & $72 b$ & $17.9 a$ & $60.9 c$ & $1.72 a$ & $38 b$ \\
\hline & Mean & 83 & 144 & 113.4 & 25 & 14.7 & 53.2 & 1.45 & 42 \\
\hline
\end{tabular}

Significant differences at $P<.01$ are indicated by different letters (Duncan test).

Means followed by the same letters do not differ significantly; Duncan test at $P<.01$

the case for Foggia 2007 where branching was intensely expressed, independent of sowing date. This might be attributable to greater persistence of low temperatures during winter months in Foggia. Sowing dates did not greatly affect head diameter, even if lower values were recorded in Valenzano 2008. 1000-seed weight, on the other hand, was significantly influenced by sowing date with S1 registering the higher 1000-seed weights both in Foggia 2007 (66.7 g) and Valenzano 2008 (66.4). Analysis of hull/seed ratio would be required, however, to clarify the potential impact of hull on 1000 seed weight. Seed yield was also affected by sowing dates with S2 (1.45) and S3 (1.45) registering higher values than S1 (1.32 t/ha). Seed yields for the early sowing date (S1) was lower than seed yields for S2 and S3. Finally, oil content in S2 (41\%) and S3 (42\%) were significantly higher than in S1 $(38 \%)$.

In general, results point to a favourable response to the S3 sowing date. While there were no significant differences between S2 and S3 for days to flowering, branching, plant height, and head diameter, S3 is preferable for the lower number of days for flowering and for closing "seed to seed" cycle in advance. Similarly, the best results were obtained for 1000-seed weight, seed yield, and oil content in the S3 experiment.

Mean values for each hybrid in the three sowing dates and location-year combinations were used in subsequent pattern analysis based on ordination and classification procedures. Principal component analysis was carried out to reduce information on response across the three sowing dates and location-year combinations. Ordination allowed the relative proximity of hybrid performances to be visualized in a reduced spatial model that also indicates directions of major variation. The first three vectors obtained by ordination for all traits accounted for 74,82 , and $87 \%$ of total variation (Table 5). In particular, if we consider the association of coefficients between original and transformed variables, or "eigenvectors" estimated for S1, first component (35\%) shows differences in hybrid behaviour for oil content (.49), and head diameter (.44). Second component (27\%) shows different behaviour for days to flowering (.57), 1000 seed weight $(-.49)$, and percent of germination (.45). Branching (-.63), plant height (.49), and seed yield (.47) show high loadings in third component. For S2 first component (42\%) shows differences in hybrid behaviour for branching (.49) and days to flowering $(-.45)$. Second component $(26 \%)$ shows different behaviour for oil content (.51), plant height (.43) and head diameter (.40). Seed yield (.60) and percent of germination (.60) show high loadings in third component. For S3 first component (55\%) shows differences in hybrid behaviour for days to flowering (-.43), branching (.42), and 100 seed weight (.38). Second component (24\%) shows different behaviour for plant height (.60), oil content (.40), and head diameter (.39). Seed yield (.68) and percent of germination (.51) show high loadings in third component. Principal component analysis indicates that oil content and seed yield traits are not strictly associated with a single component. Seed yield is always related to third component, while oil content and other plant traits are more prevalent in first and second components. Principal component analysis has also been used to show individual hybrid performances in the three location-year combinations. Hybrids grown in Foggia 2007 (code 3), plotted on the right, show high values for percent of branching, 1000-seed weight, and early flowering. Those grown in Valenzano 2008 (2), plotted on the left, show low values for the above, while hybrids grown in Valenzano 2007 (1), plotted in the middle, show higher values for oil content, head diameter, and plant height.

Hybrid performances were arranged into 11 cluster groups according to means and stability using Ward's minimum variance. Appropriate number of clusters was found by building consensus between $\mathrm{R}^{2}$, CCC, PSF, and PST $^{2}$ factors. Values for $\mathrm{R}^{2}, \mathrm{CCC}, \mathrm{PSF}$, and $\mathrm{PST}^{2}$, which are 
TABle 5: Principal component analysis of traits associated with eleven sunflower hybrids showing eigenvalues and proportion of variation relating to the first three principal component axes and eigenvectors of traits in three sowing dates and over three location-year combinations.

\begin{tabular}{|c|c|c|c|c|c|c|c|c|c|}
\hline \multirow{4}{*}{ Trait } & \multicolumn{9}{|c|}{ Sowing date } \\
\hline & \multicolumn{3}{|c|}{$\mathrm{S} 1$} & \multicolumn{3}{|c|}{$\mathrm{S} 2$} & \multicolumn{3}{|c|}{ S3 } \\
\hline & PC 1 & PC 2 & PC 3 & PC 1 & PC 2 & PC 3 & PC 1 & PC 2 & PC 3 \\
\hline & \multicolumn{9}{|c|}{ Eigenvectors } \\
\hline Germination & -.24 & 0.45 & 0.24 & -.35 & -.11 & 0.60 & -.38 & -.16 & 0.51 \\
\hline Days to flowering & 0.11 & 0.57 & -.16 & -.45 & 0.33 & 0.15 & -.43 & 0.22 & -.19 \\
\hline Plant height & 0.34 & -.27 & 0.49 & 0.28 & 0.43 & -.23 & 0.13 & 0.60 & -.45 \\
\hline Branching & 0.30 & -.14 & -.63 & 0.49 & 0.03 & -.08 & 0.42 & -.14 & -.05 \\
\hline Head diameter & 0.44 & -.24 & -.17 & 0.36 & 0.40 & 0.26 & 0.38 & 0.39 & 0.13 \\
\hline 1000 seed weight & -.31 & -.49 & -.08 & 0.31 & -.35 & 0.28 & 0.38 & -.27 & -.00 \\
\hline Seed yield & 0.44 & -.02 & 0.47 & 0.22 & 0.38 & 0.60 & 0.28 & 0.41 & 0.68 \\
\hline Oil content & 0.49 & 0.29 & -.14 & -.29 & 0.51 & -.24 & -.34 & 0.40 & 0.14 \\
\hline Eigenvalues & 2.77 & 2.13 & 1.03 & 3.36 & 2.09 & 1.12 & 4.41 & 1.89 & 0.68 \\
\hline Variance (\%) & 35 & 27 & 13 & 42 & 26 & 14 & 55 & 24 & 9 \\
\hline Cum. Var. (\%) & & 61 & 74 & & 68 & 82 & & 79 & 87 \\
\hline
\end{tabular}

TABLE 6: Ward's minimum variance cluster analysis: RSQ, CCC, PSF, and PST ${ }^{2}$ statistics.

\begin{tabular}{|c|c|c|c|c|c|c|c|c|c|c|c|c|}
\hline \multirow{3}{*}{$\begin{array}{l}\text { Number } \\
\text { of } \\
\text { Clusters }\end{array}$} & \multicolumn{12}{|c|}{ Sowing date } \\
\hline & \multicolumn{4}{|c|}{ S1 } & \multicolumn{4}{|c|}{ S2 } & \multicolumn{4}{|c|}{ S3 } \\
\hline & RSQ & CCC & PSF & $\mathrm{PST}^{2}$ & RSQ & CCC & PSF & $\mathrm{PST}^{2}$ & RSQ & CCC & PSF & $\mathrm{PST}^{2}$ \\
\hline 8 & .85 & 2.99 & 71.6 & 51.4 & .81 & 1.31 & 53.1 & 18.1 & .84 & 0.33 & 69.3 & 11.3 \\
\hline 7 & .83 & 2.53 & 72.7 & 10.9 & .78 & 0.60 & 52.4 & 14.3 & .82 & -.32 & 67.6 & 23.6 \\
\hline 6 & .80 & 1.56 & 73.6 & 20.2 & .75 & 0.28 & 53.7 & 26.2 & .79 & -.60 & 68.5 & 31.5 \\
\hline 5 & .75 & 0.29 & 69.9 & 26.5 & .71 & 0.24 & 56.8 & 19.7 & .75 & -.77 & 70.5 & 16.2 \\
\hline 4 & .67 & -1.5 & 63.5 & 33.8 & .61 & -2.7 & 48.6 & 36.6 & .66 & -2.8 & 60.5 & 40.9 \\
\hline 3 & .57 & -2.5 & 63.3 & 32.2 & .50 & -3.3 & 47.9 & 33.2 & .56 & -3.5 & 59.4 & 27.4 \\
\hline 2 & .41 & -.1 .8 & 66.2 & 37.1 & .29 & -2.9 & 38.6 & 44.8 & .35 & -2.6 & 61.5 & 61.0 \\
\hline 1 & .00 & 0.00 & - & 66.2 & .00 & 0.00 & - & 38.6 & .00 & 0.00 & - & 51.5 \\
\hline
\end{tabular}

listed in Table 6, were calculated separately for each sowing date. CCC values for S1 had a local peak in 3 clusters, while $\mathrm{PSF}$ and $\mathrm{PST}^{2}$ were found in 6 and 2 clusters, respectively. A high percentage of $\mathrm{R}^{2}(75 \%)$ was found in 5 clusters. This percentage seemed a useful way to define the number of clusters to be considered. As similar trends were observed for S2 and S3, we decided to consider 5 clusters for each sowing date. Clustering results were combined with principal component analysis results as a visual aid for discerning clusters in subsequent graphical representation (Figures 2, 3, and 4). Solaris (code A), Proleic 204 (C), Carnia (D), Alliance RM (E), Kasol (F), 1-UD (H), 2-UD (I), and 4UD $(\mathrm{K})$ hybrids showed similar behaviour in at least two location-year combinations for the early sowing date (S1). Remaining hybrids Montijo, Best, and 3-UD were present in three separate clusters. Lower uniformity was found for Carnia (D), Best (G), 1-UD (H), 2-UD (I), 3UD (J), and 4$\mathrm{UD}(\mathrm{K})$ hybrids for $\mathrm{S} 2$. A relative homogeneous response was obtained for Montijo (B), Carnia (D), Best (G), 1-UD (H), 2UD (I), and 4-UD (K) hybrids for the late sowing date S3.

\section{Discussion}

Sunflower hybrids used in this research were all genetically constituted to be grown in environments of Central Northern Italy under conventional cycles, where water deficit and summer drought are not as intense as in Southern Italy. Comparing our results on sunflower with similar research is complicated by absence, or obsolescence of data. While research by Gimeno et al. [4] has been carried out on sunflower hybrid performance during winter conditions in Mediterranean climates, this was performed by a conventional cycle under irrigation. Their findings suggest winter or early spring sowing in sites with mild temperatures can lead to yield increases of 0.5 to $0.8 \mathrm{tha}^{-1}$. This was not, however, confirmed by our own rainfall experimental conditions where the shift in sunflower sowing dates from spring to autumn-winter resulted in consistent seed yield reduction, even if oil content seemed to remain constant compared to data obtained by conventional cycle. Our research findings also agree with findings of other authors 


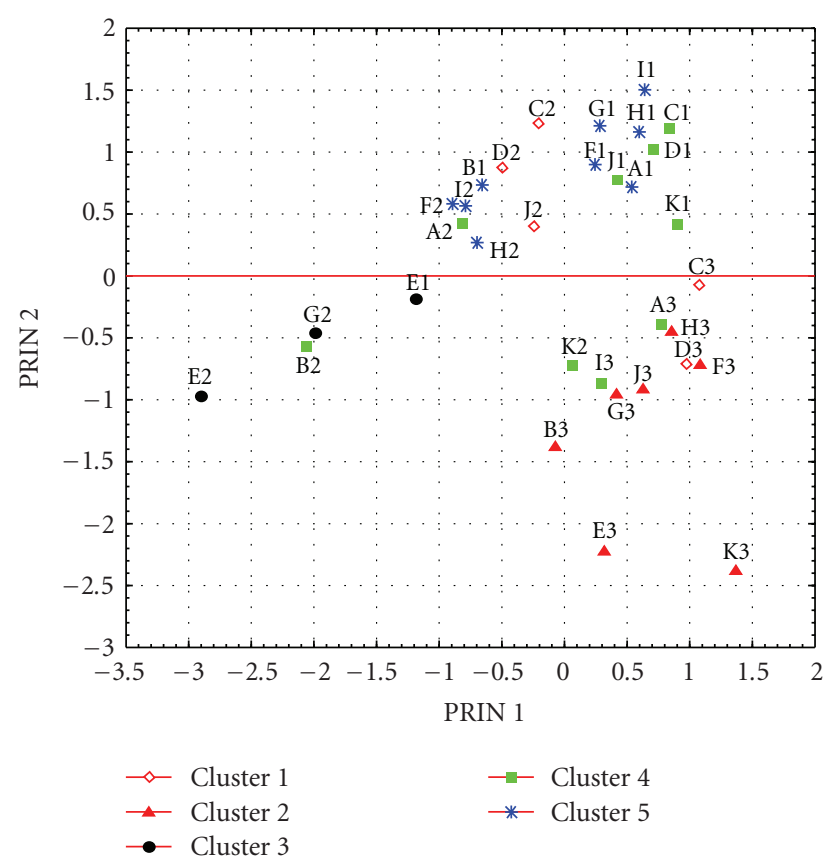

FIGURE 2: Graphic representation of hybrid behaviour according to first two principal components and identification of clusters for early sowing date (S1). Behaviour is represented by a letter (hybrid code) and number (location-year code).

$[21,33,34]$ who have reported relatively constant content for seed oil and oil yield/ha under early sowing, which then decreases with delayed sowing. Similarly, Miller et al. [23] have reported fairly constant seed oil concentration under dry-land conditions, with a slight 1.8\% increase for a conventional cycle utilising irrigation.

Genetic differences may be, furthermore, emphasised during autumn-winter cycle due to adverse conditions relating to scarcity of water, low temperatures, and radiation. According to De La Vega and Hall [34], genotype x sowing date interaction may be caused by differences in partially identifiable adaptive trait combinations that can be exploited by selection for specific adaptation. Halvorson et al. [5] have again shown that water scarcity and water stress greatly reduces sunflower yield potential, while water supply tend to increase yields. In any case, uniform water distribution is essential during phenological stages of sunflower, particularly during flowering, anthesis, and grain filling.

In our own autumn-winter trials, favourable germination percentages of plantlets were expressed since average minimum autumn temperatures were above $0^{\circ} \mathrm{C}$. Benvenuti and Vannozzi [3] have also found sunflower withstands $-5^{\circ} \mathrm{C}$ while preserving germination efficiency. Kumar and Bhatla [10] have observed in turn that sunflower seeds under high moisture conditions tolerate chilling even if they fail to acclimatise to freezing conditions, circumstances which are extremely rare in a Mediterranean climate. According to Vranceanu [35], sunflower needs a total amount of $1600-2800^{\circ} \mathrm{C}$ hours above $5^{\circ} \mathrm{C}$ (base temperature) to complete "seed to seed" cycle. Sunflower hybrids sown in

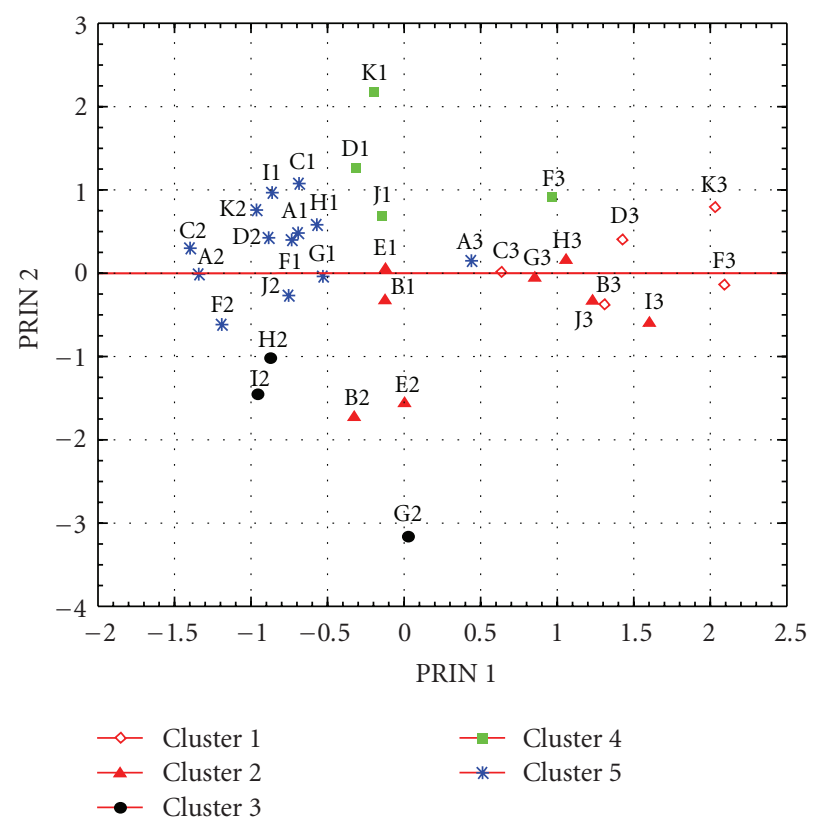

FIGURE 3: Graphic representation of hybrid behaviour according to first two principal components and identification of clusters for early sowing date (S2). Behaviour is represented by a letter (hybrid code) and a number (location-year code).

autumn-winter, when low temperatures can occur during initial stages, might also accumulate hours above $5^{\circ} \mathrm{C}$ during April-July, resulting in longer total cycle duration. It has been demonstrated that temperatures higher than $25^{\circ} \mathrm{C}$ during reproductive stages can reduce total cycle duration [36]. Farhatullah and Khalil [37] have shown that while delay in sunflower crop cycle duration does not affect oil seed content, it has a negative effect on plant yield. If this tends to be supported by our data, environmental conditions, and in particular low temperatures and water shortage during floral initiation, can cause terminal bud injuries and lead to branching which has a negative effect on seed yield (see review [1]). In our study all hybrids showed $100 \%$ branching (data not shown) with small secondary heads, suggesting that winter weather conditions, in terms of water and temperature, promote branching and keep oil content. Farhatullah and Khalil [37] have found a positive correlation between seed yield and oil content both at genotypic and phenotypic levels, but a negative correlation at environmental level between oil content and 1000-seed weight. Similarly, Tang et al. [38] have found a negative correlation between oil content and both 1000-seed and pericarp weight, but a positive correlation between oil content and kernel-to-pericarp weight ratio. Our hypothesis is that adverse environmental conditions during autumnwinter sowing, low radiation, and scarce water affect grain filling and determine a high pericarp content to 1000 seed weight.

By categorising behaviour of sunflower hybrids into similar groups with similar response patterns (11 hybrids), 


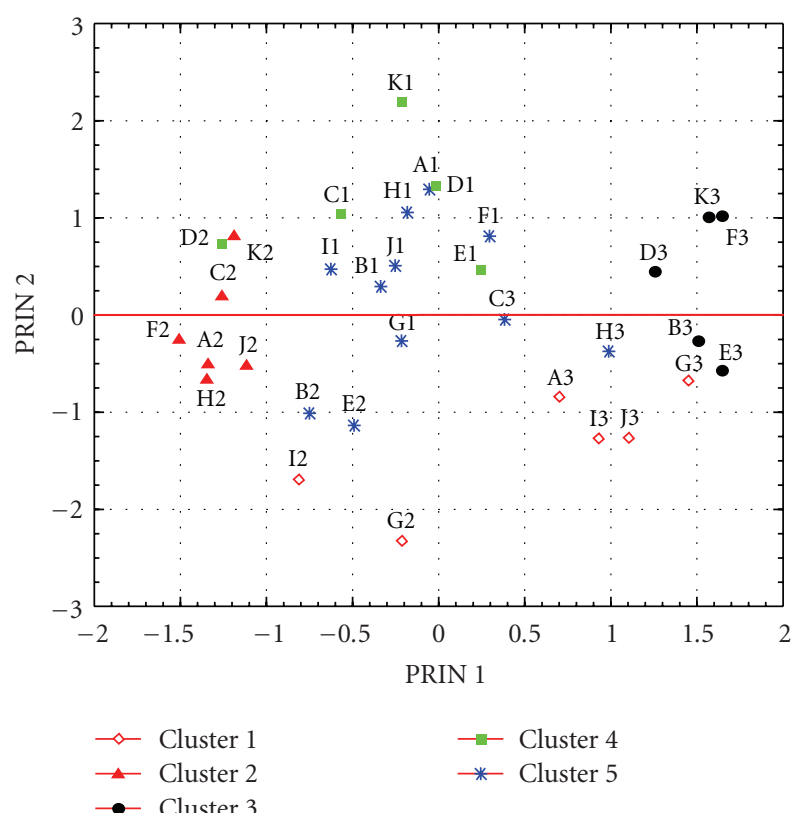

FIGURE 4: Graphic representation of hybrid behaviour according to first two principal components and identification of clusters for early sowing date (S3). Behaviour is represented by a letter (hybrid code) and a number (location-year code).

and so simplifying the process of identification of differences in response into subsets (clusters), we have been able to identify the relative stability of several sunflower hybrids in three location-year combinations. Results would tend to confirm the effectiveness of classification and ordination procedures in delimiting groups of hybrids which differed in performance and within which individual hybrids had a relatively homogeneous response. Utilizing combined principal components and cluster analyses to examine hybrid performances has therefore enabled us to identify the best and most stable sunflower hybrids for each sowing date.

In conclusion, given that the hybrids used for this research were all genetically constituted to be grown under a conventional cycle with water supply, a reduction of productive traits was to be expected for an autumn-winter sowing date. All things considered, however, the shift from early spring to autumn-winter suggests that sunflower can be used as an alternative crop to wheat monoculture in Mediterranean areas, since sunflower can exploit autumn and spring rains, thus reducing the need for irrigation, and guaranteeing constant oil production. A more detailed study to find appropriate strategies and sunflower genotypes that give good responses in early season sowing is necessary. One possible strategy, which is currently under study, could be to increase plant density in sunflower cultivation.

\section{Acknowledgments}

Research was funded by the University of Bari projects: Ateneo 2008 and Ateneo PRINCOFIN 2006 and 2007.
The authors would like to thank Dr. Mladen Todorovic, researcher at the Mediterranean Agronomic Institute of Bari, MAIAB for providing meteorological data for the experimental station at Valenzano.

\section{References}

[1] C. C. Jan and G. J. Seiler, "Sunflower" in Genetic Resources, Chromosome Engineering, and Crop Improvement, R. J. Singh, Ed., vol. 4 of Oilseed Crops, pp. 103-165, Taylor \& Francis, Boca Raton, Fla, USA, 2007.

[2] J. O. Alza and J. M. Fernandez-Martinez, "Genetic analysis of yield and related traits in sunflower (Helianthus annuus L.) in dryland and irrigated environments," Euphytica, vol. 95, no. 2, pp. 243-251, 1997.

[3] A. Benvenuti and G. P. Vannozzi, "Girasole (Helianthus annus)," in Coltivazioni Erbacee. Piante Oleifere, da Zucchero, da Fibra, Orticole e Aromatiche, R. Baldoni and L. Giardini, Eds., pp. 59-95, Patron Editore, Bologna, Italy, 2001.

[4] V. Gimeno, J. M. Fernández-Martínez, and E. Fereres, "Winter planting as a means of drought escape in sunflower," Field Crops Research, vol. 22, no. 4, pp. 307-316, 1989.

[5] A. D. Halvorson, A. L. Black, J. M. Krupinsky, S. D. Merrill, and D. L. Tanaka, "Sunflower response to tillage and nitrogen fertilization under intensive cropping in a wheat rotation," Agronomy Journal, vol. 91, no. 4, pp. 637-642, 1999.

[6] D. Skoric, "Sunflower breeding," Journal of Edible Oil Industry, vol. 25, pp. 1-90, 1988.

[7] G. N. Fick and J. F. Miller, "Sunflower breeding," in Sunflower Technology and Production, A. A. Schneiter, Ed., pp. 395-439, ASA, CSSA, and SSSA, Madison, Wis, USA, 1997.

[8] A. O. Demir, A. T. Göksoy, H. Büyükcangaz, Z. M. Turan, and E. S. Köksal, "Deficit irrigation of sunflower (Helianthus annuus L.) in a sub-humid climate," Irrigation Science, vol. 24, no. 4, pp. 279-289, 2006.

[9] R. G. Robinson, "Sunflower phenology-year, variety and date of plant effect on day and growing degree-day summations," Crop Science, vol. 11, pp. 635-638, 1971.

[10] A. Kumar and S. C. Bhatla, "Polypeptide markers for low temperature stress during seed germination in sunflower," Biologia Plantarum, vol. 50, no. 1, pp. 81-86, 2006.

[11] G. N. Fick, "Breeding and genetics," in Sunflower Science and Technology, J. F. Carter, Ed., Agronomy Monograph, no. 19, pp. 279-338, ASA, CSSA, and SSSA, Madison, Wis, USA, 1978.

[12] C. N. Akem and K. E. Dashiell, "Effect of planting date on severity of frogeye leaf spot and grain yield of soybeans," Crop Protection, vol. 13, no. 8, pp. 607-610, 1994.

[13] D. B. Egli and W. Bruening, "Planting date and soybean yield: evaluation of environmental effects with a crop simulation model: SOYGRO," Agricultural and Forest Meteorology, vol. 62, no. 1-2, pp. 19-29, 1992.

[14] B. R. R. Rao, "Biomass and essential oil yields of cornmint (Mentha arvensis L. f. piperascens Malinvaud ex Holmes) planted in different months in semi-arid tropical climate," Industrial Crops and Products, vol. 10, no. 2, pp. 107-113, 1999.

[15] J. Treder, "Effects of supplementary lighting on flowering, plant quality and nutrient requirements of lily "Laura Lee" during winter forcing," Scientia Horticulturae, vol. 98, no. 1, pp. 37-47, 2003.

[16] F. J. Adamsen and T. A. Coffelt, "Planting date effects on flowering, seed yield, and oil content of rape and crambe cultivars," Industrial Crops and Products, vol. 21, no. 3, pp. 293-307, 2005. 
[17] C. Toker, "Preliminary screening and selection for cold tolerance in annual wild Cicer species," Genetic Resources and Crop Evolution, vol. 52, no. 1, pp. 1-5, 2005.

[18] G. Kar, H. N. Verma, and R. Singh, "Effects of winter crop and supplemental irrigation on crop yield, water use efficiency and profitability in rainfed rice based cropping system of eastern India," Agricultural Water Management, vol. 79, no. 3, pp. 280292, 2006.

[19] A. D. Doyle, "Influence of temperature and daylength on phenology of sunflower in the field," Australian Journal of Experimental Agriculture and Animal Husbandry, vol. 15, pp. 88-92, 1975.

[20] W. K. Anderson, R. C. G. Smith, and J. R. McWilliam, "A systems approach to the adaptation of sunflower to new environments II. Effects of temperature and radiation on growth and yield," Field Crops Research, vol. 1, pp. 153-163, 1978.

[21] P. W. Unger, "Sowing date effects on growth, yield and oil of irrigated sunflower," Agronomy Journal, vol. 72, pp. 914-916, 1980.

[22] P. J. Goyne, G. L. Hammer, and D. R. Woodruff, "Phenology of sunflower cultivars. I. Classification of responses ( Helianthus annuus)," Australian Journal of Agricultural Research, vol. 33, no. 2, pp. 243-250, 1982.

[23] B. C. Miller, E. S. Oplinger, R. Rand, J. Peters, and G. Weis, "Effect of sowing date and plant population on sunflower performance," Agronomy Journal, vol. 76, pp. 511-515, 1984.

[24] T. O. Holtzer, R. L. Anderson, M. P. McMullen, and F. B. Peairs, "Integrated pest management of insects, plant pathogens, and weeds in dryland cropping systems of the Great Plains," Journal of Production Agriculture, vol. 9, no. 2, pp. 200-208, 1996.

[25] J. M. Krupinsky, K. L. Bailey, M. P. McMullen, B. D. Gossen, and T. K. Turkington, "Managing plant disease risk in diversified cropping systems," Agronomy Journal, vol. 94, no. 2, pp. 198-209, 2002.

[26] A. M. Johnston, D. L. Tanaka, P. R. Miller et al., "Oilseed crops for semiarid cropping systems in the northern Great Plains," Agronomy Journal, vol. 94, no. 2, pp. 231-240, 2002.

[27] M. Granlund and D. C. Zimmerman, "Oil content of sunflower seed as determined by wide-line nuclear magnetic resonance (NMR)," Proceedings of the National Academy of Sciences, vol. 27, pp. 128-133, 1975.

[28] V. E. Mungomery, R. Shorter, and D. E. Byth, "Genotype $\mathrm{x}$ environment interactions and environmental adaptationI: pattern analysis-application to soya bean populations," Austarlian Journal of Agricultural Research, vol. 25, pp. 59-72, 1974.

[29] G. B. Polignano, V. Bisignano, V. Tomaselli, P. Uggenti, V. Alba, and C. Della Gatta, "Genotype x environment interaction in grass pea (Lathyrus sativus L.) lines," International Journal of Agronomy, vol. 2009, Article ID 898396, 7 pages, 2009.

[30] SAS Institute Inc., SAS Procedures Guide for Personal Computers, SAS Institute Inc., Cary, NC, USA, 8th edition, 1989.

[31] F. Begemann, Ecogeographic differentiation of bambara groundnut (Vigna subterranea) in the collection of the International Institute of Tropical Agriculture, Thesis, Wissenschaftlicher Fachverlag, SudetenstraBe, Germany, 1988.

[32] STATSOFT Inc., STATISTICA for Windows. Vol II. Graphics, STATSOFT Inc., Tulsa, Okla, USA, 2nd edition, 1995.

[33] M. P. Bange, G. L. Hammer, and K. G. Rickert, "Environmental control of potential yield of sunflower in the subtropics," Australian Journal of Agriculture Research, vol. 48, no. 2, pp. 231-240, 1997.
[34] A. J. De la Vega and A. J. Hall, "Effects of planting date, genotype, and their interactions on sunflower yield: II. Components of oil yield," Crop Science, vol. 42, no. 4, pp. 1202-1210, 2002.

[35] A. V. Vranceanu, Floarea-Soarelui, Academiei RSR, 1974, El Girasol, Ediciones Mundi-Prensa, Madrid, Spain, 1977.

[36] H. M. Rawson, R. L. Dunstone, M. J. Long, and J. E. Begg, "Canopy development, light interception and seed production in sunflower as influenced by temperature and radiation," Australian Journal of Plant Physiology, vol. 11, no. 4, pp. 255265, 1984

[37] A. F. E. Farhatullah and I. H. Khalil, "Path analysis of the coefficients of sunflower (Helianthus annuus L.) hybrids," International Journal of Agriculture and Biology, vol. 8, no. 5, pp. 621-625, 2006.

[38] S. Tang, A. Leon, W. C. Bridges, and S. J. Knapp, "Quantitative trait loci for genetically correlated seed traits are tightly linked to branching and pericarp pigment loci in sunflower," Crop Science, vol. 46, no. 2, pp. 721-734, 2006. 


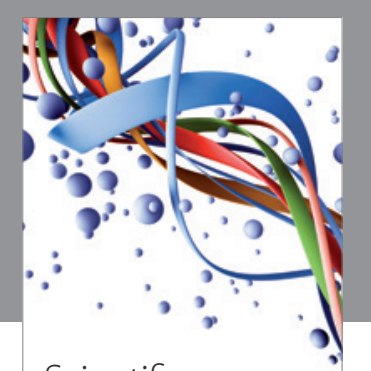

Scientifica
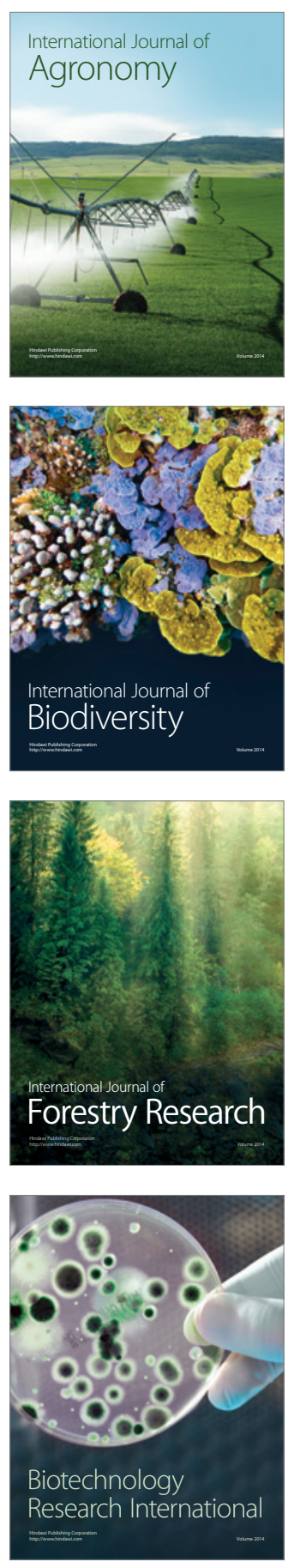
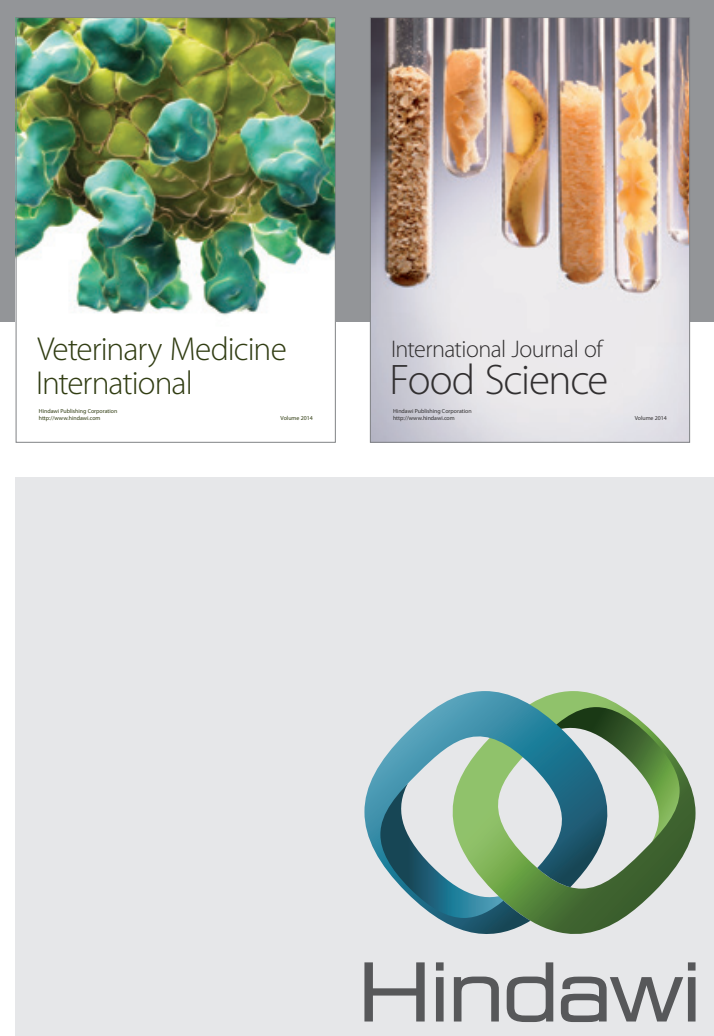

Submit your manuscripts at

http://www.hindawi.com
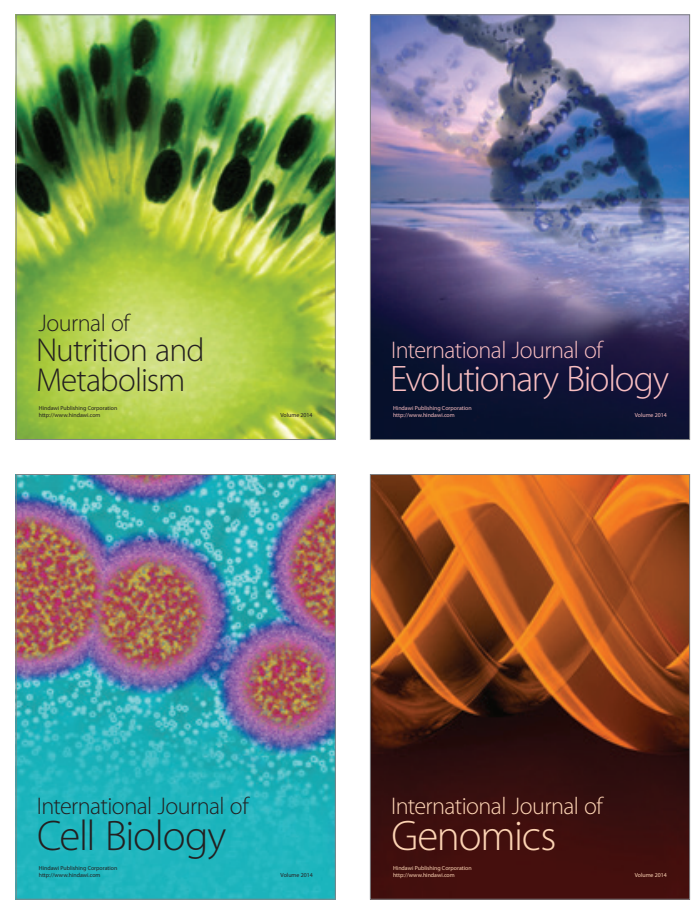
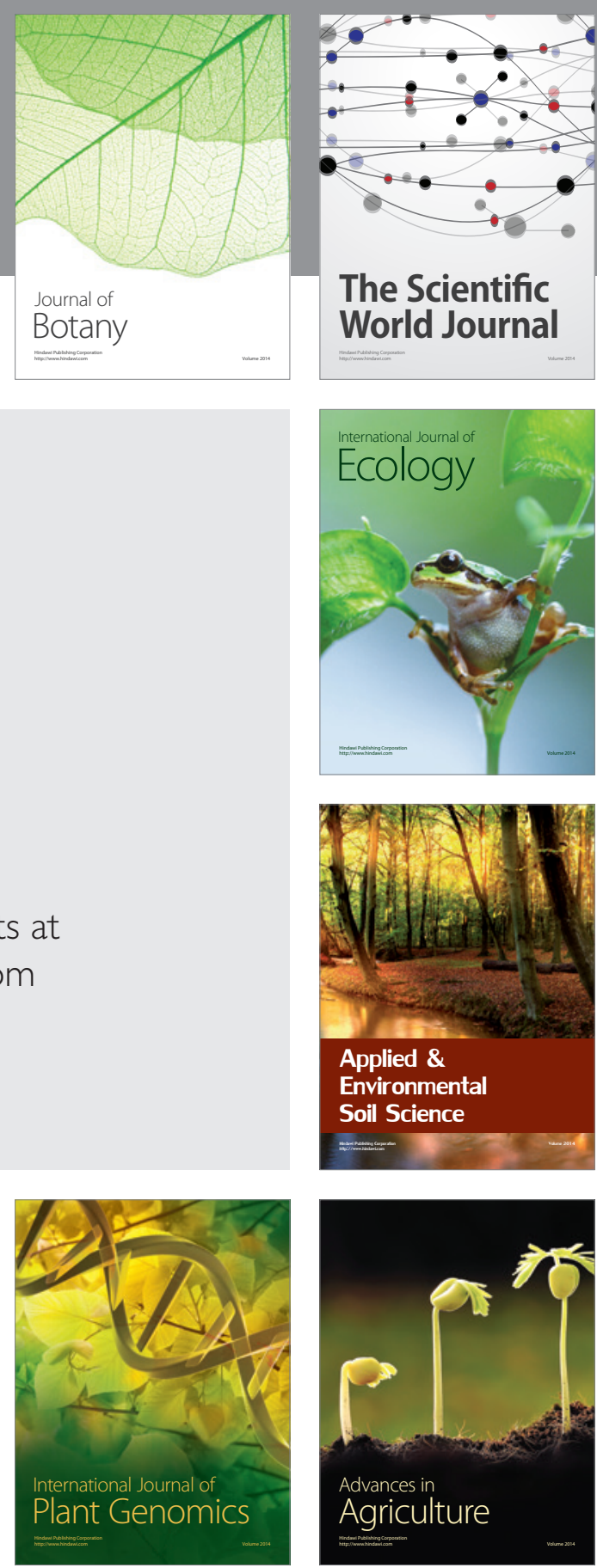

The Scientific World Journal
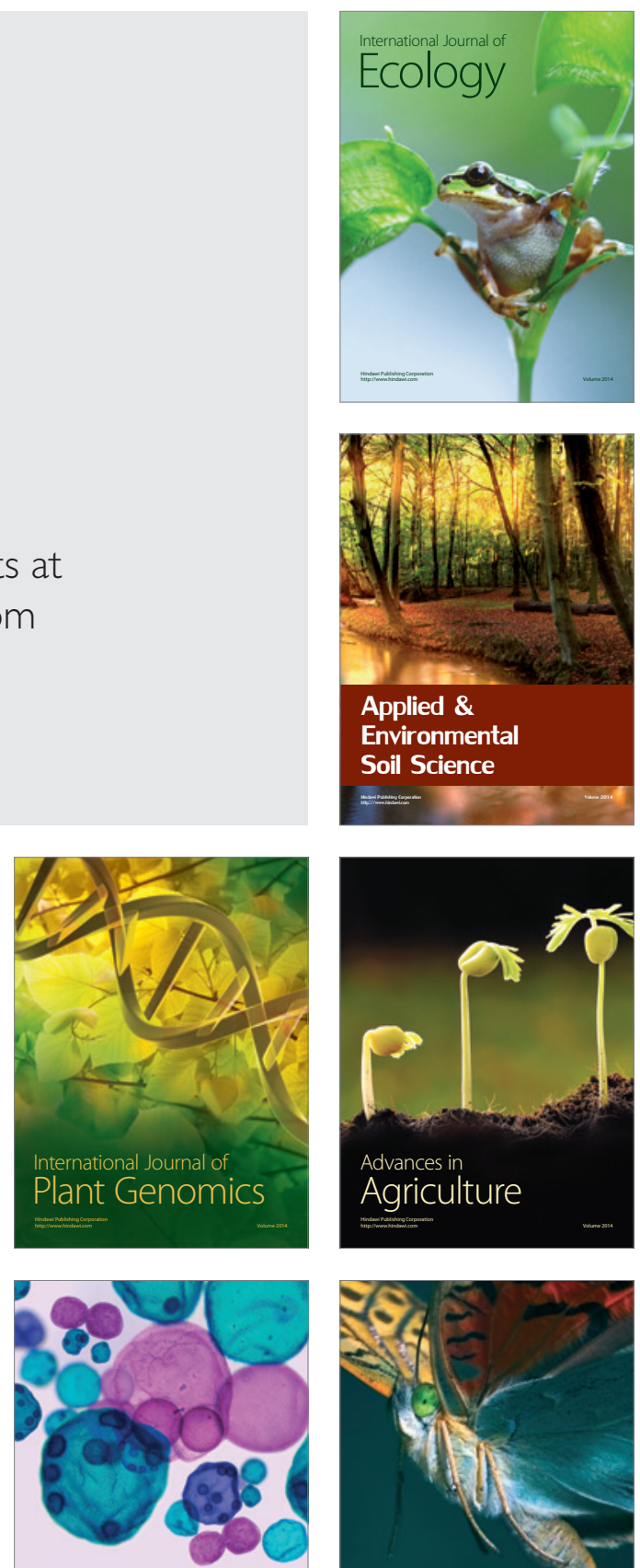

International Journal of Microbiology

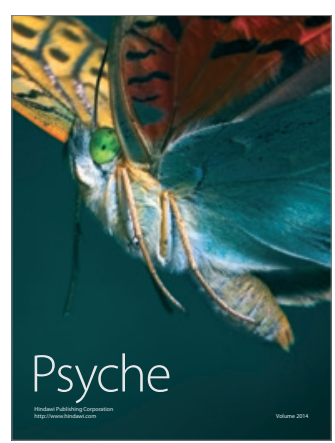

